\title{
ARTICLES
}

Submitted 04.16.2013. Approved 10.01.2013

Evaluated by double blind review process. Scientific Editor: Wilson Toshiro Nakamura

http://dx.doi.org/10.1590/S0034-759020140509

\section{STOCK EXCHANGE LISTING INDUCES SOPHISTICATION OF CAPITAL BUDGETING}

\author{
Listagem em bolsa induz sofisticação do orçamento de capital \\ La cotización bursátil lleva al perfeccionamiento de la presupuestación de capital
}

\begin{abstract}
This article compares capital budgeting techniques employed in listed and unlisted companies in Brazil. We surveyed the Chief Financial Officers (CFOs) of 398 listed companies and 300 large unlisted companies, and based on 91 respondents, the results suggest that the CFOs of listed companies tend to use less simplistic methods more often, for example: NPV and CAPM, and that CFOs of unlisted companies are less likely to estimate the cost of equity, despite being large companies. These findings indicate that stock exchange listing may require greater sophistication of the capital budgeting process.
\end{abstract}

KEYWORDS / Capital budgeting, finance survey, financial decisions, corporate finance, financial innovation.

\section{RESUMO}

Este artigo compara técnicas de orçamento de capital empregadas nas empresas listadas e não-listadas no Brasil. Emprega-se um survey dirigido aos Chief Financial Officers (CFOs) de 398 empresas listadas e 300 grandes empresas não-listadas e, com base em 91 respondentes, os resultados sugerem que os CFOs das empresas listadas tendem a usar mais intensamente métodos menos simplistas, e.g. VPL e CAPM, e que CFOs de empresas não-listadas menos provavelmente estimam o custo de capital próprio, mesmo se tratando de empresas de grande porte. Esses achados indicam que a listagem em bolsa pode requerer maior sofisticação do processo de orçamento de capital.

PALAVRAS-CLAVE / Orçamento de Capital, survey em finanças, decisões financeiras, finanças corporativas, inovação financeira.

WESLEY MENDES-DA-SILVA mr.mendesdasilva@gmail.com Professor at Marriott School of Management, The Brigham Young University - Provo - Utah, United States

\section{RICHARD SAITO}

richard.saito@fgv.br

Professor at Escola de Administração de Empresas de São Paulo, Fundação Getulio Vargas - São Paulo - SP, Brazil

\section{RESUMEN}

El presente artículo compara las técnicas de presupuestación empleadas por las empresas brasileñas cotizadas y no cotizadas. Encuestamos a los Gerentes de Finanzas Corporativos (Chief Financial Officers, CFO) de 398 empresas cotizadas y 300 grandes empresas no cotizadas, $y$, con base en 91 encuestados, los resultados sugieren que los CFO de las empresas cotizadas tienden a usar con más frecuencia métodos menos simplistas; por ejemplo: NPV y CAPM, y los CFO de las empresas no cotizadas son menos propensos a estimar el costo de los fondos propios, a pesar de tratarse de grandes empresas. Estos resultados indican que la cotización de la bolsa de valores puede requerir un mayor perfeccionamiento del proceso de presupuestación de capital.

PALABRAS CLAVE I Presupuestación de capital, encuesta financiera, decisiones financieras, finanzas corporativas, innovación financiera. 


\section{MOTIVATION}

Studies that use surveys can contribute to the development of knowledge in Finance, taking into account the possibility of obtaining data often unavailable elsewhere (Rea \& Parker, 1997; Baker \& Mukherjee, 2007; Neuhauser, 2007). There are important issues concerning financial decisions that remain scarcely investigated, especially in the emerging markets (Lazaridis, 2004; Hermes, Smid, \& Yao, 2007). Among the financial decisions, capital budgeting is a significantly important topic, when dealing with the practices adopted by financial managers, in determining which projects can best lead to the maximization of shareholder value. In recent years, authors such as Levine (1997) have indicated decreased demand for more simplistic financial decisions, e.g. Payback and accounting ratios. This would be due to economic growth, which increases the sophistication of financial markets (Scott \& Petty II, 1984).

In the last 20 years, Brazil has experienced: i) relative economic and political stability; ii) capital market growth above the global average; iii) increased adoption of good corporate governance practices (Mendes-Da-Silva \& Onusic, 2012). Nevertheless, surveys concerning the decision-making process employed by companies reveal that the topic is very rarely studied - at the level of companies listed on the stock exchange, and especially when considering unlisted companies (Balbinotti, Benetti, \& Terra, 2007; Frezatti, Bido, Cruz, Barroso, \& Machado, 2012). This makes it interesting to investigate the impact of the sophistication of management quality and of national economic growth on financial management practices, e.g., capital budgeting. This study assumes the argument found in the literature, that companies listed on the stock exchange tend to have more sophisticated mechanisms for decision-making, or rather, less simplistic than unlisted companies, as a result of the need to report to the market (Booth, 1996; Drury \& Tayles, 1996; Lazaridis, 2004).

Finance literature has provided evidence from around the world concerning the capital budgeting of companies, e.g., Graham and Harvey (2001), Lazardis (2004), Du Toit and Pienaar (2005), Hermes et al., (2007). This article is similar to the latter, in that it uses an adaptation of its data collection instrument. In addition, in light of limited knowledge of the Brazilian context, the main contribution of this work is based on presenting Brazilian evidence, interesting both researchers and practitioners. Furthermore, according to Graham (2011), it constitutes a tool for teaching Corporate Finance.

By surveying 698 Brazilian companies (398 listed and 300 unlisted), the primary objective of this work is to comparatively analyze the use of capital budgeting techniques by large listed and unlisted companies. Based on 91 responding companies, the main findings suggest that the Chief Financial Officers (CFOs) of listed companies tend to use less simplistic techniques, e.g., NPV and CAPM, compared to the CFOs of major unlisted companies. The latter tend not to estimate the cost of capital, suggesting some level of precariousness in the capital budgeting process, which supports recent arguments by Jacobs and Shivdasani (2012).

This article is organized into 6 Sections, including this introduction. Section 2 discusses previous studies regarding capital budgeting practices. Section 3 aims at reviewing the determinants of the capital budgeting practices. Section 4 details the methodological procedures used in developing this study. Section 5 empirically analyzes the determinants for the use of capital budgeting practices. Lastly, the final considerations are presented.

\section{PREVIOUS STUDIES REGARDING CAPITAL BUDGETING PRACTICES}

From a modern standpoint, the cost of capital for companies is one of the most important aspects in capital budgeting decision-making (Jacobs \& Shivdasani, 2012). Surveys about Brazilian practices are still scarce, among which: Balbinotti et al., (2007), focused on the methodological aspects of a survey about financial decisions (i.e. translation and validation of questionnaires), and Frezatti et al., (2012), who studied longterm financial decisions, considering primarily unlisted companies. This article contributes to the literature by focusing on the determinants of capital budgeting practices, comparing listed and unlisted companies. Among the Finance studies featuring surveys, one of the categories found in the literature focuses on capital budgeting practices and techniques adopted by the company (Gitman \& Forrester, 1977; Schall, Sundem, \& Geijsbeek, 1978; Bierman, 1993; Ryan \& Ryan, 2002).

According to Hermes et al., (2007), this research primarily deals with four capital budgeting techniques: i) Net Present Value (NPV); ii) Internal Rate of Return (IRR); iii) Payback (PB); and iv) Accounting Rate of Return (ARR), often used for research in the field of Finance, although there are other less frequently used techniques, e.g., Real Options (Brounen, De Jong, \& Koedijk, 2004). An opportunity worthy of attention in Finance research is the verification of the CFOs' level of interest in these traditional capital budgeting techniques, considering that since the 1960s, literature has documented the interest of practitioners around the world (Miller, 1960; Istvan, 1961; Graham \& Harvey, 2001; Du Toit \& Pienaar, 2005; Hermes et al., 2007). Frezatti et al., (2012) in- 
dicate the limited number of studies on capital budgeting practices in Brazil, even though this material is important for companies' performance and competitiveness, regardless of their level of maturity and size (Vos \& Vos, 2000; Danielson \& Scott, 2005).

The international literature on the use of different capital budgeting techniques by financial managers has been characterized by studies conducted in economies whose characteristics differ significantly from the Brazilian context (Bierman, 1993; Graham \& Harvey, 2002), although studies in emerging economies can be found (Du Toit \& Pienaar, 2005). Namely, the research conducted by Gitman and Forrester (1997), in the United States; Brounen et al., (2004), in Europe; Hermes et al., (2007), who compared the practices adopted in China and the Netherlands.

Hermes et al., (2007) support the viewpoint that, over time, the use of more sophisticated capital budgeting methods has become more common. These authors argued that this phenomenon is mainly due to: i) the financial markets have developed over time, leading to the use of more relevant, convenient and necessary methods, e.g., Discounted Cash Flow (DCF); ii) CFOs' training has increased over time; iii) advancement of the computational apparatus available to the CFOs; iv) reduced costs associated with acquiring technology.

\section{DETERMINANTS OF THE CAPITAL BUDGETING PRACTICES}

Assuming that investing decisions are made by individuals, would it be a mistake to assume that the managers' personal preferences and environmental conditions may influence the capital budgeting decision (Hermes et al., 2007) and, by extension, the company's value? The literature has documented a wide range of motives that determine the choice of capital budgeting practices. According to Klammer (1972), in the late 1950s, less than $20 \%$ of North American companies used DCF techniques as the primary method for selecting projects. In the early 1970 s, this percentage was already $57 \%$. In the following decade, Hendricks (1983) noted that $76 \%$ of companies used DCF methods as the primary decision tool.

The number of companies that used more simplistic methods, for example PB, was reduced from $34 \%$ in 1959 , to $11 \%$ of North American companies in 1981 (Hendricks, 1981). Along the same lines, Trahan and Gitman (1995), considering companies listed in the North American financial media, showed that larger companies tend to make greater use of more sophisticated capital budgeting techniques, e.g., DCF techniques. In Asia, Kester et al., (1999) obtained results suggesting an increasing relevance of DCF techniques, but still predominantly non-DCF techniques, i.e., PB.

\section{SURVEY DESIGN AND METHODOLOGY}

To collect data for this study, we had access to the questionnaire used by Hermes et al., (2007, p. 636), composed of seven questions. First, we proceeded with the adaptations, by observing the recommended practices with regard to the translation and validation of questionnaires used in finance surveys, detailed by Balbinotti et al., (2007, pp. 29-33). Specifically, we made the following changes: i) translation from English to Portuguese, done by a qualified professional; ii) pre-test with 5 CFOs, members of the Brazilian Institute of Finance Executives; iii) inclusion of the Governance variable, missing from the original questionnaire.

The questionnaire was used to survey the 398 companies listed in the BM\&FBovespa and the 300 major companies not listed on the stock exchange, but listed in a traditional business media publication in the Brazilian market: Exame 1000 Maiores e Melhores (Editora Abril, 2012). In September and November of 2012, the questionnaires were sent/received (by mail) to/from CFOs of these companies. Each mailed envelope contained: the questionnaire, with a letter detailing the intentions of the study, its voluntary nature and the preservation of respondent anonymity; and a stamped envelope for the CFOs' responses.

Of the 698 letters, 17 were returned due to the company's change of address ( 9 were from listed companies), 52 valid responses were received from listed companies, and another 39 from unlisted companies. This response rate $(\sim 13.4 \%)$ is similar to those obtained in previous studies of the same topic, e.g., Traham and Gitman (1995), 12\%; Kester et al., (1999), 15.5\%; Graham and Harvey (2001), 9\%; and Brounen et al., (2004), 5\%. With the intention of verifying the representativeness of the group of respondent companies, albeit less detailed (since the respondents could not be identified, to encourage the CFOs' participation), among the listed companies we verified the proportion of respondent companies, in comparison to the companies present in the BM\&FBovespa, through their governance level. We checked, through a non-parametric independence test, and did not find significant evidence of self-selection biases among listed companies, which was impossible to test among unlisted companies.

The survey consisted of: i) closed questions about the company's capital budgeting techniques; ii) specific questions about the company's characteristics, e.g., size, sales to international markets, type of ownership and operating sector; iii) questions regarding the CFO's profile, e.g., age and educational level. In relation to the questions associated with the use of capital budgeting techniques, the CFOs were asked to indicate: i) the frequency of use of different project evaluation techniques 
(using a scale of $1-6$, where $1=$ Never and $6=$ Always); ii) the most commonly used method for estimating cost of capital; iii) the use of methods for estimating cost of equity; iv) problems associated with the use of DCF methods; and v) the reasons for using non-DCF methods.

The dependent (dummy) variables related to the capital budgeting methods (Table 6) and the methods of estimating cost of capital (Table 7) will receive the value $=1$ if the score given by the respondent was $\geq 5$ (on a scale of 1 to 6 , where $1=\mathrm{Nev}$ er and $6=$ Always), and zero if otherwise. Based on the variables related to the profiles of the company and the CFO, we used binary response regressions (1) to verify the existence of associations between these variables and the company's tendency to use certain capital budgeting techniques.

$$
\pi_{i}=\pi(Y=1 \mid X)=F\left(Z_{i}\right)=\frac{1}{1+e^{-Z_{i}}}=\frac{1}{1+e^{-\left(\beta_{0}+\beta Z_{i}\right)}}
$$

The dependent variables related to the problems with using DCF and reasons for using non-DCF techniques (Table 8) will receive the value $=1$ when indicated by the respondent, and zero when they were not chosen by the CFO. The independent variables used were:

Listed Company $=1$ if the company is listed on the stock exchange (BM\&FBovespa), and zero if otherwise.

Size of Company $=1$ if the company's annual sales equal or exceed BRL $\$ 300,000,000$, and zero if otherwise.

CFO's Education $=1$ if the company's CFO has a Doctorate or Masters, and zero if the CFO has a lower level of education.

CFO's Age $=1$ if the company's CFO is at least 49 years old, or zero if the CFO is younger.

Governance $=1$ if the company is listed on BM\&FBovespa's Novo Mercado (New Market) of, and zero if otherwise;

Operational Sector $=1$ if the company is a manufacturer, and zero if otherwise.

With respect to capital budgeting techniques, we chose to list four of them explicitly in the questionnaire, in order to address those most commonly used by practitioners (Brounen et al., 2004; Hermes et al., 2007). The respondent was provided the opportunity to indicate other techniques used by him, as well as their frequency of use. In addition, as previously suspected, there was a low frequency of other techniques, e.g., Real Options or Sensitivity Analysis. Based on this, we chose to disregard these empirical analysis techniques used.

\section{RESULTS}

The results obtained are reported in five subsections. The first describes the profiles of the company and the CFOs, and the second examines the determinants of the use of capital budgeting techniques. The third presents the frequency of cost of capital estimation techniques. The fourth reports the results of the logit regressions for capital budgeting techniques. Finally, log- it regressions related to obstacles for using DCF techniques, as well as reasons for using non-DCF techniques.

\section{Characteristics of the companies and the CFOs}

Table 1 displays the characteristics of the companies and CFOs participating in the study. More than half of the listed companies indicated that their products are not intended for the foreign market. Also, $40 \%$ of the unlisted companies reported having no export activities. It should also be noted that approximately a third of the listed companies are composed of manufacturing companies, as well as almost half of the unlisted companies. Close to $80 \%$ of the CFOs claimed to have a graduate degree.

In order to check for the existence of independence between company characteristics and stock exchange listings, we used a nonparametric test, which indicated the existence of dependency in two classes of characteristics, i.e., Operational sector $\left(X^{2}=10.876 ; p\right.$-value <0.1) and CFO's Age ( $X^{2}=7.515$; $\mathrm{p}$-value $<0.1)$. Concerning company size, the unlisted companies have higher sales. Or rather, while $80 \%$ of the listed companies have sales over BRL\$90 million, nearly $90 \%$ of unlisted companies are in this sales range. When considering sales abroad, we found that $\sim 54 \%$ of the listed companies do not sell to the international market, while $43.6 \%$ of unlisted companies concentrate $100 \%$ of their sales in the domestic market.

As for the CFOs' characteristics, in general, there seems to be a greater frequency of professionals with a graduate level of education in the listed companies, i.e., $21.2 \%$ of the CFOs of these companies claim to have a Masters or Doctorate. This percentage is similar to that found by Hermes et al., (2007), p. 637) for the Chinese market, and lower than that found in the Netherlands, $33 \%$. Among the 39 unlisted companies, only $15.4 \%$ have this education level, in other words, it seems that among the companies not listed on the stock exchange, there is a predominance of professionals with an educational level equivalent to MBAs, i.e., training programs with an executive focus. 
TABLE 1. Characteristics of the companies and the responding CFOs

\begin{tabular}{|c|c|c|c|c|c|}
\hline Company characteristics & \multicolumn{2}{|c|}{ Listed } & \multicolumn{2}{|c|}{ Unlisted } & $x^{2}$ \\
\hline Gross revenue & & & & & 4.018 \\
\hline Less than 2.4 Mil BRL\$ & 6 & 11.5 & 3 & 7.7 & \\
\hline Between 2.4 Mil BRL\$ and 16 Mil BRL\$ & 3 & 5.8 & 1 & 2.6 & \\
\hline Greater than 90 Mil BRL\$ and up to 300 Mil BRL\$ & 5 & 9.6 & 1 & 2.6 & \\
\hline Greater than 300 Mil BRL\$ & 37 & 71.2 & 34 & 87.2 & \\
\hline$\%$ of Sales abroad & & & & & 3.231 \\
\hline There are no sales for the international market & 28 & 53.8 & 17 & 43.6 & \\
\hline $50 \%-90 \%$ & 3 & 5.77 & 5 & 12.8 & \\
\hline $100 \%$ & 1 & 1.92 & 1 & 2.56 & \\
\hline Industry & & & & & $10.876^{\star}$ \\
\hline Industrial/Manufacturing & 18 & 34.6 & 19 & 48.7 & \\
\hline Transportation/Infrastructure & 7 & 13.5 & 6 & 15.4 & \\
\hline Technology & 1 & 1.92 & 1 & 2.56 & \\
\hline Financial Services & 5 & 9.62 & 0 & 0 & \\
\hline Energy & 10 & 19.2 & 1 & 2.56 & \\
\hline MBA & 31 & 59.6 & 25 & 64.1 & \\
\hline CFO's Age & & & & & $7.515^{*}$ \\
\hline$\leq 40$ years & 16 & 30.8 & 6 & 15.4 & \\
\hline Between 40 and 48 years & 16 & 30.8 & 17 & 43.6 & \\
\hline Between 49 and 59 years & 13 & 25 & 15 & 38.5 & \\
\hline$\geq 60$ years & 7 & 13.5 & 1 & 2.56 & \\
\hline Governance (BM\&FBovespa criteria) & & & & & - \\
\hline Traditional & 18 & 34.6 & 0 & o & \\
\hline Bovespa+ & 2 & 3.85 & 0 & 0 & \\
\hline Level 1 & 5 & 9.62 & 0 & 0 & \\
\hline Level 2 & 2 & 3.85 & 0 & 0 & \\
\hline New Market & 25 & 48.1 & 0 & o & \\
\hline
\end{tabular}

Note: $\mathrm{N}$ Listed companies $=52 ; \mathrm{N}$ Unlisted companies $=39 .{ }^{*} \mathrm{p}$-value $<0.1$. The test statistic $\mathrm{x}^{2}$ suggests the existence of dependence between stock exchange listing and two company characteristics, i.e., Operational sector $\left(x^{2}=10.876\right)$ and CFO's Age $\left(x^{2}=7.515\right)$. 
TABLE 2. Intensity of use of different capital budgeting methods by CFOs

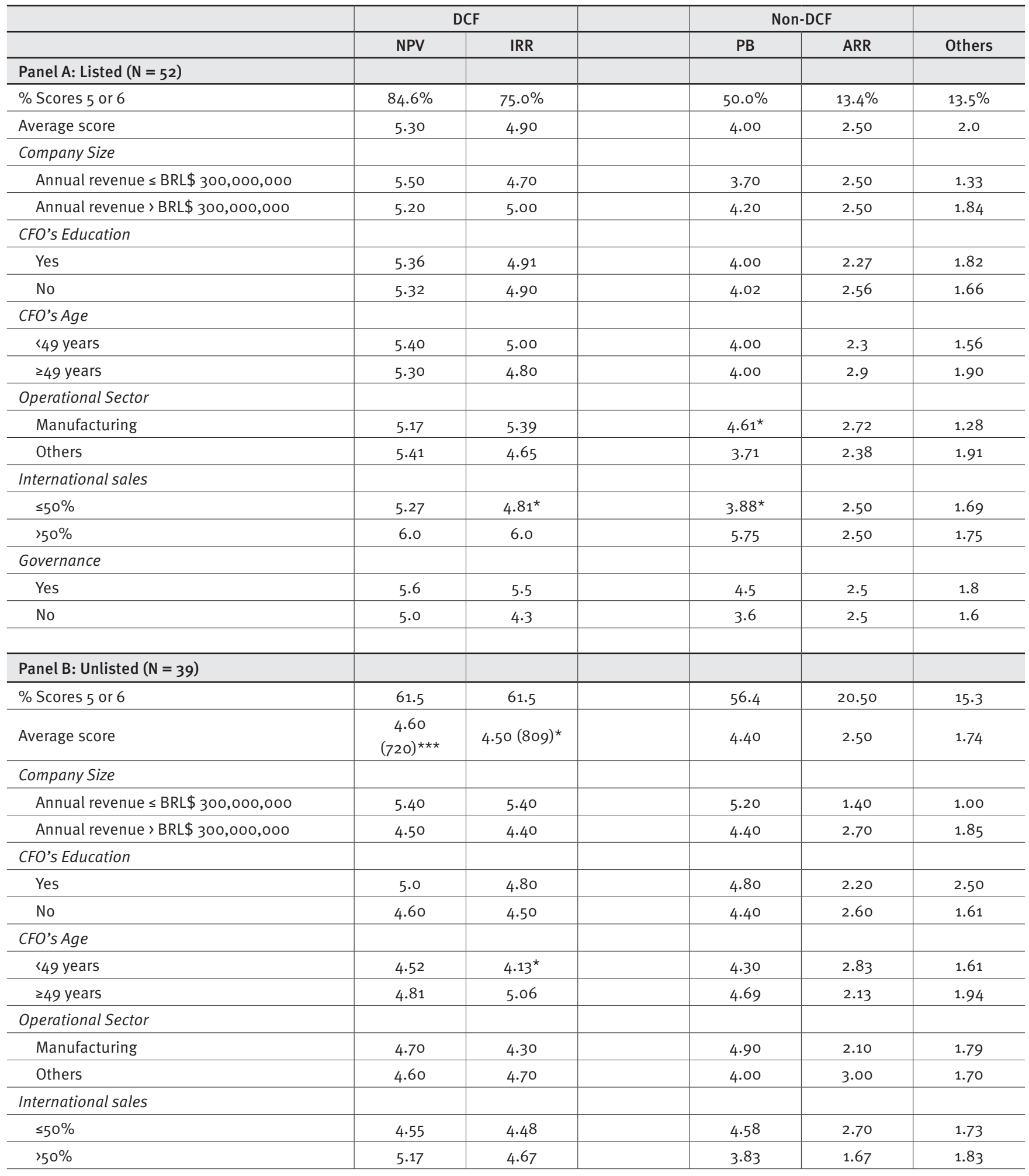

Note: The line "\% Scores 5 or 6 " shows the percentage of companies that indicated using a capital budgeting method Always (score =6) or Almost always (score =5). The line "Average score" presents the average score given by the CFOs, using a scale of 0 (never) to 6 (always). The other lines show the average score for different categories, based on the company's characteristics. We checked for independence (Mann-Whitney test) between the company and CFO profiles, and the intensity of use of the capital budgeting techniques (significance indicated beside each average value). The numbers in italics and between parentheses are nonparametric test statistics, comparing the average values between listed companies and unlisted companies. The averages for the company categories were different from each other. The results indicate that the two groups of companies use DCF techniques, i.e., NPV and IRR, with different levels of intensity. ${ }^{\star}$ p-value $<$ $0.1 ;{ }^{* *}$ p-value $<0.5 ;{ }^{* * *}$ p-value $<0.01$ 
Thus, we noted that $64.1 \%$ of the executives of these companies have at most an MBA. On the other hand, this percentage fell to $59.6 \%$ in listed companies. As for the CFOs' age, we noted that $\sim 80 \%$ of the executives of unlisted companies are between 40 and 59 years old. On the other hand, this percentage was less than $56 \%$ for listed companies. Finally, concerning the adoption of corporate governance practices identified as recommended, 25 companies ( $48 \%$ of the listed companies) belong to the New Market.

\section{Capital budgeting techniques adopted by the companies}

Table 2 shows the results related to the use of capital budgeting techniques among various company profiles. In a similar manner to that of Graham and Harvey (2001), Brounen et al., (2004) and Hermes et al., (2007), we asked how often various capital budgeting methods are used, using a 6-point scale (where $1=$ Never and 6 = Always).

This provides information about the methods currently used by CFOs for capital budgeting decisions, as well as the relative importance of these different methods. The following capital budgeting techniques were used - DCF methods: NPV and IRR; and non-DCF methods: PB and ARR, and other techniques listed by the respondents, e.g., EBITDA.

From a technical standpoint, the NPV is the least simplistic technique, followed by the IRR (Hermes, et al., 2007). Moreover, the non-DCF techniques are regarded as less accurate and less sophisticated, in particular the PB. We found that $84.6 \%$ of the CFOs of listed companies claimed to use the NPV always or almost always (scores $\geq 5$ ). This percentage is close to that found by Hermes et al., (2007) for the Dutch market ( $89 \%)$, and higher than that found in China (49\%). However, in Brazil, according to the responses provided by the CFOs of unlisted companies, this percentage falls to $61.5 \%$. Nevertheless, regardless or being listed or unlisted on the Stock Exchange, the companies seem to indicate NPV as the most used method, making it the most popular among respondents.

It is worth noting, however, that according to the responses for unlisted companies, the scores given to the NPV are very close to those obtained by the IRR. That is, both the NPV and the IRR were indicated by $\sim 61.5 \%$ of the CFOs. This response was not found with the listed companies, among which the IRR was found to be less commonly used than the NPV. We also found that non-DCF techniques seem to be more heavily used by the CFOs of unlisted companies. This observation is consistent with the lower educational level of the CFOs. In other words, the findings suggest an association between the CFO's educational level and their preference for capital budgeting techniques. As such, it seems that the non-DCF techniques, which are less accurate and more simplistic, may be preferred by the CFOs with a lower educational level.

\section{Methods for estimating cost of capital}

With regard to the methods for estimating the cost of capital, which is an important and necessary aspect for DCF techniques, e.g., NPV and IRR, we asked that the CFOs indicate which methods they used most often to estimate the cost of capital (Table 3).

It is understood that, the cost of capital adjusted to the risk of each project, as well as the WACC constitute less simplistic techniques. The cost of debt $\left(\mathrm{k}_{\mathrm{d}}\right)$ is explicitly less sophisticated than both of these, despite situations in which projects are fully financed with debt issuances. Table 3 shows that $37 \%$ of the listed companies claim to use the WACC as the discount rate for cash flows in evaluating their projects. Table 4, on the other hand, presents the responses obtained for different methods that companies use to calculate their cost of equity $\left(k_{e}\right)$. An aspect worth mentioning is that, according to the contents of Table 4, among the listed companies, $11 \%$ claim not to calculate $\mathrm{k}_{\mathrm{e}}$. Among the unlisted companies, this percentage is $\sim 31 \%$.

This suggests a certain precariousness of the decision-making process for capital budgeting, to the extent that the unfamiliarity with $\mathrm{k}_{\mathrm{e}}$ may lead to significant mistakes in decision making, whether by accepting or rejecting investment projects. A similar phenomenon was recently observed by Jacobs and Shivdasani (2012) in the North American market. In these authors' opinion, most companies have used erroneous premises to calculate the cost of capital. Therefore, they tend to make financial decisions that are not aligned with the goal of creating value for the company.

This becomes more problematic when dealing with smaller companies in the domestic market. Perhaps, unfamiliarity with the $\mathrm{k}_{\mathrm{e}}$ is greater, when considering the set of unlisted companies. However, considering other emerging economies, the number of companies that pay no attention to calculating the $k_{e}$ is even greater. Thus, Hermes et al., (2007) indicates that over $64 \%$ of the Chinese companies do not. It should be noted that this work does not explore the advantages of more complex methods, such as Real Options, over DCF methods, such as NPV (Copeland \& Antikarov, 2003). 
TABLE 3. Most commonly used methods for measuring the cost of capital (\% of total)

\begin{tabular}{|c|c|c|c|c|c|}
\hline & \multicolumn{5}{|c|}{ Rates used as a proxy for cost of capital } \\
\hline & $\begin{array}{c}\text { Specific k of each } \\
\text { project }\end{array}$ & WACC & $K_{d}$ & $\mathrm{~K}_{\mathrm{e}}$ & Other methods \\
\hline \multirow[t]{2}{*}{ Panel A: Listed $(\mathrm{N}=52)$} & 5.0 & 37.0 & 4.0 & 6.0 & 0.0 \\
\hline & 9.6 & 71.2 & 7.7 & 11.5 & 0.0 \\
\hline \multicolumn{6}{|l|}{ Company Size } \\
\hline Annual revenue $\leq \mathrm{BRL} \$ 300,000,000$ & $13 \cdot 3$ & 80.0 & 6.7 & 0.0 & 0.0 \\
\hline Annual revenue > BRL $\$ 300,000,000$ & 8.1 & 67.6 & 8.1 & 16.2 & 0.0 \\
\hline \multicolumn{6}{|l|}{ CFO's Education } \\
\hline No & 9.8 & 68.3 & 7.3 & 14.6 & 0.0 \\
\hline Yes & 9.1 & 81.8 & 9.1 & 0.0 & 0.0 \\
\hline \multicolumn{6}{|l|}{ CFO's Age } \\
\hline$<49$ years & 6.3 & 75.0 & 9.4 & 9.4 & 0.0 \\
\hline$\geq 49$ years & 15.0 & 65.0 & 5.0 & 15.0 & 0.0 \\
\hline \multicolumn{6}{|l|}{ Operational Sector } \\
\hline Others & 11.8 & 73.5 & 5.9 & 8.8 & 0.0 \\
\hline Manufacturing & 5.6 & 66.7 & 11.1 & 16.7 & 0.0 \\
\hline \multicolumn{6}{|l|}{ International sales > $50 \%$} \\
\hline No & 10.4 & 72.9 & 8.3 & 8.3 & 0.0 \\
\hline Yes & 0.0 & 50.0 & 0.0 & 50.0 & 0.0 \\
\hline \multicolumn{6}{|l|}{ Governance } \\
\hline No & 18.5 & 63.0 & 14.8 & 3.7 & 0.0 \\
\hline Yes & 0.0 & 80.0 & 0.0 & 20.0 & 0.0 \\
\hline \multirow[t]{2}{*}{ Panel B: Unlisted ( $\mathrm{N}=39)$} & 5.0 & 24.0 & 2.0 & 3.0 & 5.0 \\
\hline & 12.8 & 61.5 & 5.1 & 7.7 & 12.7 \\
\hline \multicolumn{6}{|l|}{ Company Size } \\
\hline Annual revenue $\leq \mathrm{BRL} \$ 300,000,000$ & 20 & 20 & 20 & 40 & 0 \\
\hline Annual revenue > BRL\$ $300,000,000$ & 11.8 & 67.6 & 5.9 & $5 \cdot 9$ & 8.9 \\
\hline \multicolumn{6}{|l|}{ CFO's Education } \\
\hline No & 12.1 & 57.6 & 6.1 & 9.1 & 15.1 \\
\hline Yes & 16.7 & 83.3 & 0 & 0 & 0 \\
\hline \multicolumn{6}{|l|}{ CFO's Age } \\
\hline «9 years & 13.0 & 65.2 & 4.3 & $4 \cdot 3$ & 13.1 \\
\hline$\geq 49$ years & 12.5 & 56.25 & 6.25 & 12.5 & 12.5 \\
\hline \multicolumn{6}{|l|}{ Operational Sector } \\
\hline Others & 70.0 & 5.0 & 15.0 & 10.0 & \\
\hline Manufacturing & 26.3 & 52.6 & $5 \cdot 3$ & 0.0 & 15.8 \\
\hline \multicolumn{6}{|l|}{ International sales > $50 \%$} \\
\hline No & 12.1 & 60.6 & 6.1 & 9.1 & 12.1 \\
\hline Yes & 16.7 & 66.7 & 0.0 & 0.0 & 16.7 \\
\hline \multicolumn{6}{|l|}{ Governance } \\
\hline No & 12.8 & 61.5 & 5.1 & 7.7 & 12.8 \\
\hline Yes & 0 & 0 & 0 & 0 & 0 \\
\hline
\end{tabular}

Note: This table presents the percentage of companies in each of the categories that indicates that a certain discount rate is used more often. The total percentages for different company categories may total more than $100 \%$ due to rounding. 
TABLE 4. Most frequently used methods for estimating the cost of equity in $\%$ of total

\begin{tabular}{|c|c|c|c|c|c|}
\hline & $\begin{array}{c}\text { Historical } \\
\text { average return }\end{array}$ & CAPM & $\begin{array}{c}\mathrm{k}_{\mathrm{e}}+\text { Premium } \\
+ \text { growth }\end{array}$ & $\begin{array}{c}\text { Does not } \\
\text { estimate } k_{e}\end{array}$ & $\begin{array}{c}\text { Other } \\
\text { methods }\end{array}$ \\
\hline Panel A: Listed $(\mathrm{N}=52)$ & 3.0 & 27.0 & 8.0 & 6.0 & 8.0 \\
\hline \multicolumn{6}{|l|}{ Company Size } \\
\hline Annual revenue $\leq \mathrm{R} \$ 300,000,000$ & $13 \cdot 3$ & $33 \cdot 3$ & 26.7 & $13 \cdot 3$ & $13 \cdot 3$ \\
\hline \multicolumn{6}{|l|}{ CFO's Education } \\
\hline No & 4.9 & 51.2 & 14.6 & 12.2 & 17.1 \\
\hline Yes & 9.1 & 54.5 & 18.2 & 9.1 & 9.1 \\
\hline \multicolumn{6}{|l|}{ CFO's Age } \\
\hline$<49$ years & 3.1 & 56.3 & 15.6 & 12.5 & 12.5 \\
\hline \multicolumn{6}{|l|}{ Operational Sector } \\
\hline Others & 5.9 & 61.8 & 11.8 & 8.8 & 11.8 \\
\hline Manufacturing & 5.6 & 33.3 & 22.2 & 16.7 & 22.2 \\
\hline \multicolumn{6}{|l|}{ International sales > $50 \%$} \\
\hline No & 6.3 & 50.0 & 14.6 & 12.5 & 16.7 \\
\hline Yes & 0.0 & 75.0 & 25.0 & 0.0 & 0.0 \\
\hline \multicolumn{6}{|l|}{ Governance } \\
\hline No & 7.4 & 51.9 & 3.7 & 14.8 & 22.2 \\
\hline Yes & 4.0 & 52.0 & 28.0 & 8.0 & 8.0 \\
\hline \multicolumn{6}{|l|}{ Company Size } \\
\hline No & 0.0 & 33.3 & 12.1 & 33.3 & 21.2 \\
\hline Yes & 0.0 & 33.3 & 0.0 & 16.7 & 50.0 \\
\hline \multicolumn{6}{|l|}{ CFO's Age } \\
\hline <9 years & 0.0 & 34.8 & 13.0 & 34.8 & 17.4 \\
\hline$\geq 49$ years & 0.0 & 31.3 & 6.3 & 25.0 & 37.5 \\
\hline \multicolumn{6}{|l|}{ Operational Sector } \\
\hline Others & 0.0 & 40.0 & 10.0 & 25.0 & 25.0 \\
\hline Manufacturing & 0.0 & 26.3 & 10.5 & 36.8 & 26.3 \\
\hline \multicolumn{6}{|l|}{ International sales > $50 \%$} \\
\hline No & 0.0 & 30.3 & 12.1 & 30.3 & 27.2 \\
\hline Yes & 0.0 & 50.0 & 0.0 & $33 \cdot 3$ & 16.7 \\
\hline \multicolumn{6}{|l|}{ Governance } \\
\hline No & 0.0 & 0.0 & 0.0 & 0.0 & 0.0 \\
\hline Yes & 0.0 & 0.0 & 0.0 & 0.0 & 0.0 \\
\hline
\end{tabular}

Note: This table presents the percentage of companies in each of the categories that indicates that a certain discount rate is used more often. The total percentages for different company categories may total more than $100 \%$ due to rounding. 


\section{Capital budgeting techniques, cost of capital and estimating the cost of equity: bivariate and multivariate analysis}

This subsection addresses the results obtained from the logit models (Tables 6, 7 and 8), according to, which expresses the probability $\pi_{i}$ of the $i$-th company using certain capital budgeting techniques. In order to verify robustness, OLS regressions were performed, as an alternative to the logit model, with no differences found between the two test methods.

$$
\begin{aligned}
\pi_{i}=\ln \left(\frac{P_{i}}{1-P_{i}}\right)= & \varphi_{1}+\varphi_{2} \text { Listed Company }_{i}+\varphi_{3} \text { Company Size }_{i} \\
& +\varphi_{4} \text { CFO's Education }_{i}+\varphi_{5} \text { CFO's Age }_{i} \\
& +\varphi_{6} \text { Operational Sector }_{i}+\varphi_{7} \text { Governance }_{i}+u_{i}
\end{aligned}
$$

Where: Listed Company is the dummy variable that indicates if the $i$-th company is listed in the stock exchange (value $=1)$ or not $(v a l-$ ue $=0$ ), and other independent variables: Company Size, CFO's Education, CFO's Age, Governance and Operational Sector with as the stochastic disturbance term. Table 5 presents the correlation coefficients between the independent variables, noting that only Company Size showed significant correlation with Listed companies. No multicollinearity problems were found in the regressions.

\section{TABLE 5. Correlation matrix for independent variables used in the estimates}

\begin{tabular}{l|c|c|c|c|c|c}
\hline & Listed Company & & Company Size & CFO's Education & CFO's Age & Operational Sector \\
\hline Company Size & -0.192 & $*$ & & & \\
\hline CFO's Education & 0.073 & & -0.018 & & \\
\hline CFO's Age & -0.026 & & -0.059 & 0.016 & & \\
\hline Operational Sector & -0.142 & & -0.155 & -0.110 & 0.108 & -0.095 \\
\hline Governance & 0.533 & $\star \star \star$ & 0.029 & 0.084 & -0.108 \\
\hline
\end{tabular}

Note: ${ }^{*} p$-value $<0,01 ;{ }^{* *} p$-value $<0.05 ;{ }^{* * * p-v a l u e<0.1 . ~}$

In Table 6, the dependent variables were created as follows: NPV $=1$ if the score given by the company for the NPV method was $\geq 5$, and $N P V=0$ if otherwise; IRR $=1$ if the score given by the company for the IRR method was $\geq 5$, and IRR $=0$ if otherwise; $\mathrm{PB}=1$ if the score given by the company for the PB method was $\geq 5$, and $P B=0$ if otherwise. Model I suggests that the stock exchange listing increases the company's likelihood to use NPV more commonly as a capital budgeting technique $\left(\widehat{\varphi}_{2} \approx-1.235\right.$; $p$ - value $<0.05)$. This could corroborate the arguments of Levine (1997), who claimed that listed companies tend to maintain structures and practices aimed at greater sophistication of the capital budgeting decision-making process. In other words, with the development of capital markets, the investors' demand for the quality of financial decisions is expected to grow.

However, when considering the other independent variables (Model II), one can note that the Company's Size $\left(\widehat{\Phi}_{2} \approx-1.396 ; p-\right.$ value $\left.<0.1\right)$ seems to have a more expressive and significant effect on the tendency to use NPV, highlighting that smaller companies tend to use NPV less often. It is worth noting that unlisted companies are the largest (Tables 1 and 5). Model VI shows that there seems to be an association between the CFO's Age and their preference for greater use of more simplistic techniques, e.g., $\mathrm{PB}\left(\widehat{\varphi_{5}} \approx-0.829 ; \mathrm{p}-\right.$ value $\left.<0.1\right)$.

Table 7 presents the estimated coefficients for models whose dependent variables are the use of different methods for obtaining the cost of equity, as well as not calculating the $K_{e}$. The results obtained in Models VII and VIII suggest that the listed companies on the Stock Exchange are more likely to indicate the CAPM as a method for calculating the cost of equity. Thus, considering the coefficients obtained in Model VII, we observed that the effect of stock exchange listing $\left(\widehat{\phi_{2}} \approx 0.770 ; p-\right.$ value $\left.<0.1\right)$ on the probability of using CAPM as a method for calculating the cost of equity is $\sim 18.59$ percentage points. This impact is even more significant $\left(\widehat{\phi}_{2} \approx 1.086 ; p\right.$ - value $\left.<0.1\right)$ when considering the effect of Company Size, i.e., Model VIII suggests an increase of $\sim 25.46$ percentage points. A detailed discussion regarding interpretation of the estimated coefficients in the logit model can be found in Wooldridge (2011, pp. 535-548). 
TABLE 6. Determinants of the capital budgeting methods (logit)

\begin{tabular}{|c|c|c|c|c|c|c|c|c|c|c|}
\hline & \multicolumn{3}{|c|}{ NPV } & & \multicolumn{2}{|c|}{ IRR } & & \multicolumn{3}{|c|}{ PB } \\
\hline & 1 & & II & & III & IV & & v & VI & \\
\hline Constant & 0.470 & & 1.689 & * & 0.470 & 0.550 & & 0.258 & -0.776 & \\
\hline \multirow[t]{2}{*}{ Listed Company } & 1.235 & $\star \star$ & 0.506 & & 0.629 & -0.035 & & -0.258 & -0.845 & \\
\hline & $(0.506)$ & & $(0.614)$ & & $(0.459)$ & $(0.534)$ & & $(0.426)$ & $(0.566)$ & \\
\hline Company Size & & & -1.396 & * & & -0.390 & & & -0.053 & \\
\hline \multirow[t]{2}{*}{ CFO's Education } & & & 1.076 & & & 0.387 & & & 0.853 & \\
\hline & & & (0.819) & & & $(0.660)$ & & & $(0.556)$ & \\
\hline \multirow[t]{2}{*}{ CFO's Age } & & & 0.111 & & & 0.325 & & & 0.829 & * \\
\hline & & & $(0.540)$ & & & $(0.501)$ & & & $(0.487)$ & \\
\hline Operational Sector & & & -0.349 & & & 0.158 & & & 1.366 & 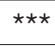 \\
\hline \#Observations & 91 & & 91 & & 91 & 91 & & 91 & 91 & \\
\hline McFadden R2 & 0.060 & & 0.135 & & 0.016 & 0.070 & & 0.002 & 0.139 & \\
\hline Akaike’s Criterion & 100.61 & & 103.02 & & 114.45 & 118.45 & & 129.51 & 122.30 & \\
\hline$\%$ correct classification & $74.7 \%$ & & $74.7 \%$ & & $69.2 \%$ & $69.2 \%$ & & $52.7 \%$ & $68.1 \%$ & \\
\hline x2 Likelihood test & 6.27 & & 13.86 & & 1.88 & 7.87 & & 0.37 & 17.57 & \\
\hline
\end{tabular}

Note: All of the models presented in this table were estimated using the logit method. In parentheses, under each coefficient, is the standard error of the estimate for each coefficient obtained. The estimates were obtained with a robust standard error using the procedure suggested by Davidson and Mackinnon (2004, p. 250). * $\mathrm{p}$-value < 0.01 ; ${ }^{* *}$ p-value $<0.05 ;{ }^{* * *}$-value $<0.1$

\section{TABLE 7. Determinants of the methods for estimating the cost of equity (logit)}

\begin{tabular}{|c|c|c|c|c|c|c|c|c|c|c|}
\hline & \multicolumn{4}{|c|}{ CAPM } & \multicolumn{3}{|c|}{$\mathrm{k}_{\mathrm{d}}+$ premium + growth } & \multicolumn{3}{|c|}{ Does not estimate $k_{e}$} \\
\hline & VII & & VIII & & IX & $x$ & & $\mathrm{XI}$ & & XII \\
\hline Constant & -0.693 & $\star \star$ & -1.420 & $\star \star$ & $-2.170^{\star \star \star}$ & -1.480 & & -0.811 & ** & -0.640 \\
\hline \multirow[t]{2}{*}{ Listed Company } & 0.770 & * & 1.086 & $\star$ & 0.464 & -1.317 & & -1.226 & ** & -0.936 \\
\hline & $(0.439)$ & & $(0.562)$ & & $(0.653)$ & $(1.138)$ & & $(0.556)$ & & $(0.676)$ \\
\hline \multirow[t]{2}{*}{ CFO's Education } & & & 0.041 & & & -0.342 & & & & -0.635 \\
\hline & & & (0.642) & & & $(0.812)$ & & & & $(0.873)$ \\
\hline \multirow[t]{2}{*}{ CFO's Age } & & & -0.279 & & & -0.203 & & & & -0.598 \\
\hline & & & $(0.477)$ & & & $(0.742)$ & & & & $(0.632)$ \\
\hline Governance & & & $(0.621)$ & & & $(1.034)$ & & & & (o.894) \\
\hline \#Observations & 91 & & 91 & & 91 & 91 & & 91 & & 91 \\
\hline McFadden R2 & 0.025 & & 0.099 & & 0.007 & 0.133 & & 0.057 & & 0.095 \\
\hline Akaike's Criterion & 125.65 & & 126.34 & & $74 \cdot 44$ & 75.476 & & 89.338 & & 95.88 \\
\hline$\%$ Correct classifications & $58.2 \%$ & & $70.3 \%$ & & $86.8 \%$ & $86.8 \%$ & & $80.2 \%$ & & $81.3 \%$ \\
\hline x2 Likelihood test & 3.16 & & 12.47 & & 0.52 & 9.48 & & 5.17 & & 8.63 \\
\hline
\end{tabular}

Note: All of the models presented in this table were estimated using the logit method. In parentheses, under each coefficient, is the standard error of the estimate for each coefficient obtained. The estimates were obtained with a robust standard error using the procedure suggested by Davidson and Mackinnon (2004, p. 250 ). ${ }^{*} \mathrm{p}$-value $<0.01$; ${ }^{* *}$-value $<0.05 ;{ }^{* * *}$ p-value $<0.1$ 
In other words, the results show that the decision to use CAPM as the technique for calculating the cost of equity is also determined by the company's size; together, these two variables significantly affect the likelihood of a company using CAPM more often. This also means that smaller companies, not listed on the stock exchange, are less likely to use CAPM very often as a method for calculating the cost of equity. This finding supports the arguments and findings of Hermes et al., (2007). Also on Table 7, Model XI presents coefficients that suggest that stock exchange listing may lead to greater willingness to calculate the cost of equity $\left(\widehat{\varphi}_{2} \approx-1.226 ; p-\right.$ value $\left.<0.05\right)$. But, when considering the other independent variables (Mod- el XII), this effect was no longer significant, despite maintaining the sign $\left(\widehat{\varphi}_{2} \approx-0.936 ; p-\right.$ value $\left.>0.1\right)$.

\section{Obstacles for the use of DCF techniques and reasons for using non-DCF techniques}

Table 8 presents the results obtained for problems identified in using DCF techniques, and the advantages of using non-DCF techniques (models XVII and XVIII). According to the results obtained in model XIV, it seems that the older CFOs (over age 50) less commonly perceive the difficultly in estimating risk as a factor that could discourage the use of DCF techniques $\left(\widehat{\phi_{5}} \approx-1.272 ; p-\right.$ value $\left.<0.05\right)$.

\section{TABLE 8. Determinants of problems and obstacles for using the DCF and determinants of the motivation for using non-DCF methods (logit)}

\begin{tabular}{|c|c|c|c|c|c|c|c|c|c|}
\hline & \multicolumn{3}{|c|}{ Difficulty estimating risk } & \multicolumn{3}{|c|}{$\begin{array}{l}\text { Difficulty including strategy in } \\
\text { the project }\end{array}$} & \multicolumn{3}{|c|}{$\begin{array}{l}\text { Other advantages of using non-DCF } \\
\text { techniques }\end{array}$} \\
\hline & XIII & XIV & & $X V$ & $\mathrm{XVI}$ & & XVII & XVIII & \\
\hline \multirow[t]{2}{*}{ Constant } & -0.154 & -1.074 & & 0.154 & 0.731 & & $-1.204^{\star \star \star}$ & -2.610 & $\star \star \star ~$ \\
\hline & $(0.321)$ & $(0.712)$ & & (0.321) & $(0.741)$ & & $(0.380)$ & (o.869) & \\
\hline Listed Company & $(0.425)$ & $(0.618)$ & & $(0.425)$ & $(0.559)$ & & (0.503) & $(0.796)$ & \\
\hline \multirow[t]{2}{*}{ Company Size } & & 0.747 & & & -0.194 & & & 1.180 & * \\
\hline & & $(0.563)$ & & & $(0.595)$ & & & $(0.714)$ & \\
\hline \multirow[t]{2}{*}{ CFO's Age } & & -1.272 & $\star \star \star$ & & 0.271 & & & 0.332 & \\
\hline & & $(0.508)$ & & & $(0.463)$ & & & $(0.545)$ & \\
\hline \multirow[t]{2}{*}{ Operational Sector } & & 1.678 & $* * \star$ & & -0.995 & ** & & 0.115 & \\
\hline & & $(0.513)$ & & & $(0.483)$ & & & $(0.586)$ & \\
\hline \multirow[t]{2}{*}{ Governance } & & 0.043 & & & -0.814 & & & 1.428 & * \\
\hline & & $(0.635)$ & & & (0.603) & & & $(0.776)$ & \\
\hline
\end{tabular}

Note: All of the models presented in this table were estimated using the logit method. In parentheses, under each coefficient, is the standard error of the estimate for each coefficient obtained. The estimates were obtained with a robust standard error using the procedure suggested by Davidson and Mackinnon (2004, p. 250). *p-value < 0.01; ${ }^{* *}$ p-value $<0.05 ;{ }^{* * *}$-value $<0.1$ 
However, the perception that the difficulty in estimating risk may be a factor that constitutes an obstacle for using DCF techniques is also explained by the company's operational sector. Rather, the manufacturing companies seem to have a greater propensity to understand the estimation of risk as an obstacle for using DCF techniques ( $\widehat{\varphi} \approx 1.678$; $p$-value $<0.01)$. Nevertheless, contrary to that obtained in Model XIV, the explanatory model of the difficulty of contemplating strategic factors in project evaluation, the manufacturing companies demonstrated a less restrictive view regarding the use of DCF techniques.

\section{DISCUSSION AND FINAL CONSIDERATIONS}

This article aimed to compare the level of use of capital budgeting techniques among companies listed in the stock exchange and large companies not listed in the stock exchange, in an emerging economy, Brazil. Based on the arguments presented in the literature, we expected that the company's level of development, e.g., stock exchange listing, would impact the capital budgeting practices adopted by the companies. The motivation for this study is based on three important factors. First, the financial markets have shown explicit development over time, including the Brazilian market (Mendes-Da-Silva \& Onusic, 2012). Therefore, one would expect the use of DCF methods to be the most suitable, convenient and necessary (Hermes et al., 2007). Second, the training level of CFOs has increased over time, which may support the adoption of more sophisticated capital budgeting techniques (Graham, 2011). Third, the increased availability of computer tools, coupled with the reduction of technology costs, may facilitate and encourage the use of more advanced techniques.

This study was developed based on a survey of 698 Brazilian companies, of which 398 were listed and 300 unlisted. Thus, from a response rate of around $13 \%$, the data set consisted of 91 companies, including both listed and unlisted. The data analysis was conducted based on nonparametric tests and logit models, which focused on the potential effect that the need to report to the market (listed companies) could have on capital budgeting practices. In other words, in order to verify if the adoption of capital budgeting practices differs significantly between listed companies and unlisted companies. Also, if these differences can be explained by the characteristics of the company and the CFO. Taking into account the growth of the Brazilian market, we found the development of this study to be interesting, since the international literature had examined the adoption of capital budgeting practices, but mainly in developed economies, or in Asian markets.
The main findings suggest that the CFOs of listed companies tend to use more sophisticated techniques, e.g., NPV (when not considering the full set of independent variables) and CAPM (even considering all of the independent variables), when compared to CFOs of the largest unlisted companies. This finding supports the arguments presented in previous works, such as the work developed by Hermes et al., (2007). Rather, taking into account the need to report to the participants of capital markets, the CFOs of listed companies seem to use the capital budgeting techniques more commonly regarded by literature as more sophisticated. This suggests the explicit need to intensify the training of CFOs who still employ less sophisticated methods for capital budgeting decision-making (Kester et al.,, 1999; Coleman, 2007; Graham, 2011).

These findings highlight two issues to consider. The first is related to the demand for CFO education, as a means to encourage the adoption of less simplistic capital budgeting practices, notably among listed companies, in view of the need to report to the market. The second issue worthy of mentioning, aside from the CFO's educational level, is the prioritization of less simplistic capital budgeting practices being subject to the performance of governance structure, i.e., the Board, pressure from investors and shareholder activism. Given the growth of the Brazilian capital market, and the specificities of this market, it is worth mentioning the importance of the performance of corporate governance structures, notably the company's Board, and the shareholders on the CFO's role, in relation to maximization of company value. Moreover, recent studies have introduced the discussion of the inappropriate use of capital budgeting techniques leading to value destruction. That is, both the adoption of projects with low attractiveness, as well as the rejection of projects with the potential to create value are undesirable for the company (Dixit \& Pindyck, 1995; Cassimon, Backer, Engelen, Wouwe, \& Yordanov, 2011).

It is important to highlight the possibility of self-selection biases in the set of respondent companies. This could result in possible distortions in research findings, i.e., companies that employ more simplistic and rudimentary methods of investment analysis may be less willing to respond to the survey, since they could attribute less importance to the topic. Thus, the findings achieved in this study may be, at least to some degree, overstated in terms of the sophistication level of the capital budgeting process at large Brazilian companies.

Aware of the limitations that may be attributed to this study, i.e., it deals with only an emerging country, possible selection biases based on the willingness to respond to the questionnaire, the relatively small number of observations, the current national and global economy; but considering the relevance 
of studies regarding capital budgeting practices, especially in emerging economies, one can see that future research may be relevant and contributory. For example: i) replicating this study in the future, checking the progress in adopting capital budgeting practices; ii) developing similar studies in other emerging economies, exploring the effect of the level of market development on the practices adopted by the CFOs; iii) expanding this study, exploring potential effects of adopting capital budgeting techniques with different levels of sophistication on the company's value; iv) given the possibility of destroying the company's value by making poor decisions, we suggest analyzing the effects of corporate governance structures and shareholder activism on capital budgeting practices employed by CFOs (Park \& Park, 2004). These issues are beyond the scope of this study, but they undoubtedly constitute good motivation for future research in the area of Finance.

\section{NOTE OF APPRECIATION}

This paper was developed in collaboration with AES Eletropaulo, through the R\&D project \#\#4690000854, focusing on financial innovation. The authors are sincerely grateful to the anonymous reviewers from $R A E$, and their suggestions and criticisms that helped improve the original manuscript of this work. We also thank the CFOs who voluntarily responded to the survey. We must also mention the two FGV-EAESP students who assisted in data collection: Henrique Consentino and Fernando Mange Niemeyer.

\section{REFERENCES}

Baker, H. K. \& Mukherjee, T. K. (2007). Survey research in finance: views from journal editors. International Journal of Managerial Finance, 3(1), $11-25$.

Balbinotti, M. A. A., Benetti, C. \& Terra, P. R. S. (2007). Translation and validation of the Graham-Harvey survey for the Brazilian context. International Journal of Managerial Finance, 3(1), 26-48.

Bierman, H. (1993). Capital budgeting in 1992: a survey. Financial Management, 22(3), 24.

Booth, L. (1996). Making capital budgeting decisions in multinational corporations. Managerial Finance, 22(1), 3-18.

Brounen, D., De Jong, A., \& Koedijk, K. (2004). Corporate finance in Europe: confronting theory with practice. Financial Management, 33(4), 71-101.
Cassimon, D., Backer, M. D., Engelen, P. J., Wouwe, M.V., \& Yordanov, V. (2011). Incorporating technical risk in compound real option models to value a pharmaceutical R\&D licensing opportunity. Research Policy, 40(9), 1200-1216.

Coleman, L. (2007). Risk and decision making by finance executives a survey study. International Journal of Managerial Finance, 3(1), 108-124.

Copeland, T. \& Antikarov, V. (2003). Real Options: Practitioner's guide. Cengage : New York.

Danielson, M. G. \& Scott, J. A. (2005). The capital budgeting decisions of small businesses. Philadelphia, PA.

Davidson, R. \& Mackinnon, J. G. (2004). Econometric theory and methods. New York: Oxford University Press.

Dixit, A. K. \& Pindyck, R. S. (1995). The options approach to capital investment. Harvard Business Review, May-June, 105-115.

Drury, C. \& Tayles, M. (1996). UK capital budgeting practices: some additional survey evidence. European Journal of Finance, 2(4), 371-388.

Du Toit, M. J. \& Pienaar, A. (2005). A review of the capital budgeting behavior of large South African firms. Meditari Accountancy Research, 13(1), 19-27.

Editora Abril. (2012). 1000 Maiores e Melhores. São Paulo, SP.

Frezatti, F., Bido, D. S., Cruz, A. P. C., Barroso, M. F. G., \& Machado, M. J. C.(2012). Decisões de investimento em ativos de longo prazo nas empresas brasileiras: qual a aderência ao modelo teórico? Revista de Administração Contemporânea, 16(1), 1-22.

Gitman, L. J. \& Forrester, J. R. (1977). A survey of capital budgeting techniques used by major U.S. firms. Financial Management, 6(3), 66-71.

Graham, J. R. (2011). Using CFO surveys as a motivational tool to teach corporate finance. Financial Review, 46(2), 193-205.

Graham, J. \& Harvey, C. (2001). The theory and practice of corporate finance: evidence from field. Journal of Financial Economics, 60(2-3), 187-243.

Graham, J. \& Harvey, C. (2002). How do CFOs make capital budgeting and capital structure decisions? Journal of Applied Corporate Finance, 15(1), 8-23.

Hendricks, J. A. (1983). Capital budgeting practices including inflation adjustments: a survey. Managerial Planning, 31(4), 22-28.

Hermes, N., Smid, P., \& Yao, L. (2007). Capital budgeting practices: a comparative study of the Netherlands and China. International Business Review, 16(5), 630-654.

Istvan, D. F. (1961). The economic evaluation of capital expenditures. Journal of Business, 34(1), 45-51.

Jacobs, M. T. \& Shivdasani, A. (2012). Do you know your cost of capital? Harvard business review. July-August, 1-8.

Kester, G., Chang, R. P., Echanis, E. S., Haikal, S., Isa, M. Md., \& Skully, M. T. (1999). Capital budgeting practices in the Asia-Pacific region: Australia, Hong Kong, Indonesia, Malaysia, Philippines, and Singapore. Financial Practice Education, 9(1), 25-33.

Klammer, T. P. (1972). Empirical evidence on the application of sophisticated capital budgeting techniques. Journal of Business, 45(3), 387-397.

Lazaridis, I. T. (2004). Capital budgeting practices: a survey in the firms in Cyprus. Journal of Small Business Management, 42(4), 427-433.

Levine, R. (1997). Financial development and economic growth: views and Agenda. Journal of Economic Literature, 35(2), 688-726.

Mendes-Da-Silva, W., \& Onusic, L. M. (2012). Corporate e-disclosure determinants: evidence from the Brazilian market. International Journal of Disclosure and Governance, 11, 54-73. doi:10.1057/jdg.2012.14 
Miller, J. H. (1960). A glimpse at practice in calculating and using return on investment. N. A. A. Bulletin (now Management Accounting) June, 65-76.

Neuhauser, K. (2007). Survey research in finance. International Journal of Managerial Finance, 3(1), 5-10.

Park, Y. \& Park, G. (2004). A new method for technology valuation in monetary value: procedure and application. Technovation, 24(5), 387-394.

Rea, L. M. \& Parker, R.A. (1997). Designing and Conducting Surveys Research, 2nd ed., Josey-Bass Publishers, San Francisco, CA.

Ryan, P. A. \& Ryan, G.P. (2002). Capital budgeting practices of the fortune 1000: how have things changed? Journal of Business and Management, 8(4), 355.
Schall, L. D., Sundem, G. L., \& Geijsbeek, W. R., Jr. (1978). Survey and analysis of capital budgeting methods. Journal of Finance, 33(1), 281-287.

Scott, D. Jr. \& Petty II, W. (1984). Capital budgeting practices in large American firms: a retrospective analysis and synthesis. Financial Review, 19(1), 111-123.

Trahan, E. A. \& Gitman, J. L. (1995). Bridging the theory-practice gap in corporate finance: a survey of chief financial officers. Quarterly Review of Economics and Finance, 35(1), 73-87.

Vos, A. \& Vos, E. (2000). Investment decision criteria in small New Zealand businesses. Small Enterprise Research, 8(1), 44-55.

Wooldridge, J. M. (2011). Introdução à Econometria, Cengage : São Paulo. 